\title{
Prediction of bio-economically sustainable yield and optimum fishing effort for the Nile tilapia (Oreochromis niloticus L.) fishery of Lake Hawassa, Ethiopia
}

\author{
Yosef Tekle-Giorgis \\ School of Animal and Range Sciences, College of Agriculture, Hawassa University, P.O.Box 336
}

\begin{abstract}
The Nile tilapia (Oreochromis niloticus, L. 1758) stock of Lake Hawassa, Ethiopia, was assessed to estimate bio-economically sustainable yield (MSY and MEY) and optimum fishing effort $\left(\mathrm{f}_{\text {opt }}\right.$ ) using length-based analytical models (Jone's Cohort Analysis and Thompson and Bell). Pertinent data (length, weight, catch, effort, etc.) were collected on a daily basis between May 2012 and June 2013 from the two landing sites, where fishermen at the northern and the southern part of the lake land their catch for retail. The assessment revealed an estimated current yield of $240.23 \mathrm{t} /$ year and $216.33 \mathrm{t}$ /year for the southern and northern part of the fishery of the lake, respectively. The predicted biologically maximum sustainable yield (MSY) was $240.2 \mathrm{t} /$ year and $218.7 \mathrm{t} / \mathrm{year}$ for the southern and northern fishery, respectively, which were obtained at an F-factor of 1 and 1.5, respectively. On the other hand, the maximum economic return was generated from the southern and northern fishery at an F- factor of 0.8 and 1.4, respectively. Therefore, the level of effort at the time of sampling (F-current) should be reduced by $20 \%$ for the southern fishery while the current effort of the northern fishery can be expanded by $40 \%$ in order to obtain the maximum economically sustainable yield. Accordingly, the optimum level of fishing effort $\left(f_{\text {opt }}\right)$ to be exerted at the lake level was estimated at about 650 nets per day in order to exploit $O$. niloticus stock of Lake Hawassa sustainably.
\end{abstract}

Keywords: Analytical yield prediction models, Lake Hawassa, MEY, MSY, optimum fishing effort, O. niloticus, stock assessment

DOI: http://dx.doi.org/10.4314/ejst.v11i1.5

\section{INTRODUCTION}

The commercial fishery of Lake Hawassa primarily rests on Oreochromis. niloticus that contributes about $90 \%$ of the total annual catch (LFDP, 1997; Elias Dadebo, 2000; Tadesse Fetahi and Seyoum Mengistou, 2007). Since the last two decades, the commercial fishery of the Ethiopian lakes has tremendously increased as the fishery is almost open to everybody who can fish. Thus some commercially important fish species like $O$. niloticus have become victims of overexploitation. Consequently, Lake Hawassa is one of the most abused lakes in the country. Starting from the early 1990's, the fishery of Lake Hawassa has been continuously expanding with a rise in the number of fishermen and fishing gears. Following this progressive increment of fishing effort, the annual fish yield in the early 1990's reached its peak at about 900 t/year (LFDP, 1997). The fishery has, however, undergone drastic changes in recent years. The yield has been continuously declining and reached about $50 \%$ of the maximum record, indicative of a dwindling fish population size probably resulting from overexploitation in the last two decades (LFDP, 1997; Reyntjens and Tesfaye Wudneh, 1998).

\footnotetext{
*Corresponding author: yosef.teklegiorgis@yahoo.com

(C) This is an Open Access article distributed under the terms of the Creative Commons Attribution License (http://creativecommons.org/licenses/CC BY4.0).
} 
Reliable yield estimates are obtained from the use of analytical type stock assessment models, and the basic input data for these types of models comprise the age and/or length composition of the total annual landings of the fishery (Thompson and Bell, 1934; Jones, 1984, Sparre and Venema, 1992). Particularly, the length based models are suitable for tropical fish stock assessment work as they do not require the tedious procedure of age determination, which is frequently difficult for tropical fish stocks. Unfortunately, the catch statistical data collection system practiced in Lake Hawassa (also in other lakes of the country as well) has not been geared towards generating age and/or length structured catch data. Hence lack of such data has mainly limited the application of analytical type models. As a result, little is known about the potential yield of the exploited fish species, even the limited information available on potential yield estimates are derived from empirical models. Therefore, in this study analytical stock assessment models have been used to estimate the maximum bio-economically sustainable yield of the most fished stock, O. niloticus, as well as the biologically and economically optimum fishing pressure to be exerted on the stock.

\section{MATERIALS AND METHODS}

\section{Site description}

Lake Hawassa $\left(6^{\circ} 33^{\prime}-7^{\circ} 33^{\prime} \mathrm{N}\right.$ and $38^{\circ} 22^{\prime}-38^{\circ} 29^{\prime}$ E) is the smallest of the seven natural lakes in the rift valley of Ethiopia (Figure 1). It is located in southern Ethiopia bordering the eastern side of Hawassa city, which is located $275 \mathrm{~km}$ south of Addis Ababa, the capital city of the country. It has an altitude of 1,680 $\mathrm{m}$ above sea level, a surface area of $90 \mathrm{~km}^{2}$, a mean depth of $11 \mathrm{~m}$, a volume of $1.036 \times 10^{9} \mathrm{~m}^{3}$ and a drainage area of $1,250 \mathrm{~km}^{2}$ (LFDP, 1997). It is a terminal lake with no surface outflow and receives surface inflow through Tikur Wuha River (LFDP, 1997).

Lake Hawassa has the most diversified phytoplankton community (i.e., over 70 species) in the rift system, amongst of which Cyanophytes (mainly Microcystis) makeup over $75 \%$ of the total algal biomass (Elizabeth Kebede, 1996). The zooplankton community comprises mainly Copepoda (Mesocyclops and Thermocyclops) and Cladocera (Diaphanosoma) (Seyoum Mengistou and Fernando, 1991). Dominant groups of benthic invertebrates in this lake are Ostracoda (comprising $>50 \%$ of numerical abundance) followed by Oligocheata and nematoda (Tudorancea et al., 1989).

Lake Hawassa is one of the most fished lakes in the rift valley. There are six fish species in the lake of which $O$. niloticus is commercially the most important contributing about $90 \%$ of the annual catch (Reyntjens and Tesfaye Wudneh, 1998). Also the African catfish (Clarias gariepinus, Burchell 1822) and the African big barb (Labeobarbus intermedius, Rüppell, 1836) contribute about $7 \%$ and $3 \%$, respectively, to the total annual catch (Reyntjens and Tesfaye Wudneh, 1998). $O$. niloticus and L. intermedius are caught exclusively by gillnets while $C$. gariepinus is caught by gillnets and long lines. The other three minnow fish species that are not fished because of their small size include the straightfin barb (Barbus paludinosis, Peters, 1852), the black lampeye (Aplocheilichthys antinorii, Vinceguera, 1883) and the stone lapping minnow (Gara quadrimaculata, Rüppell, 1835) (Elias Dadebo, 2000). 


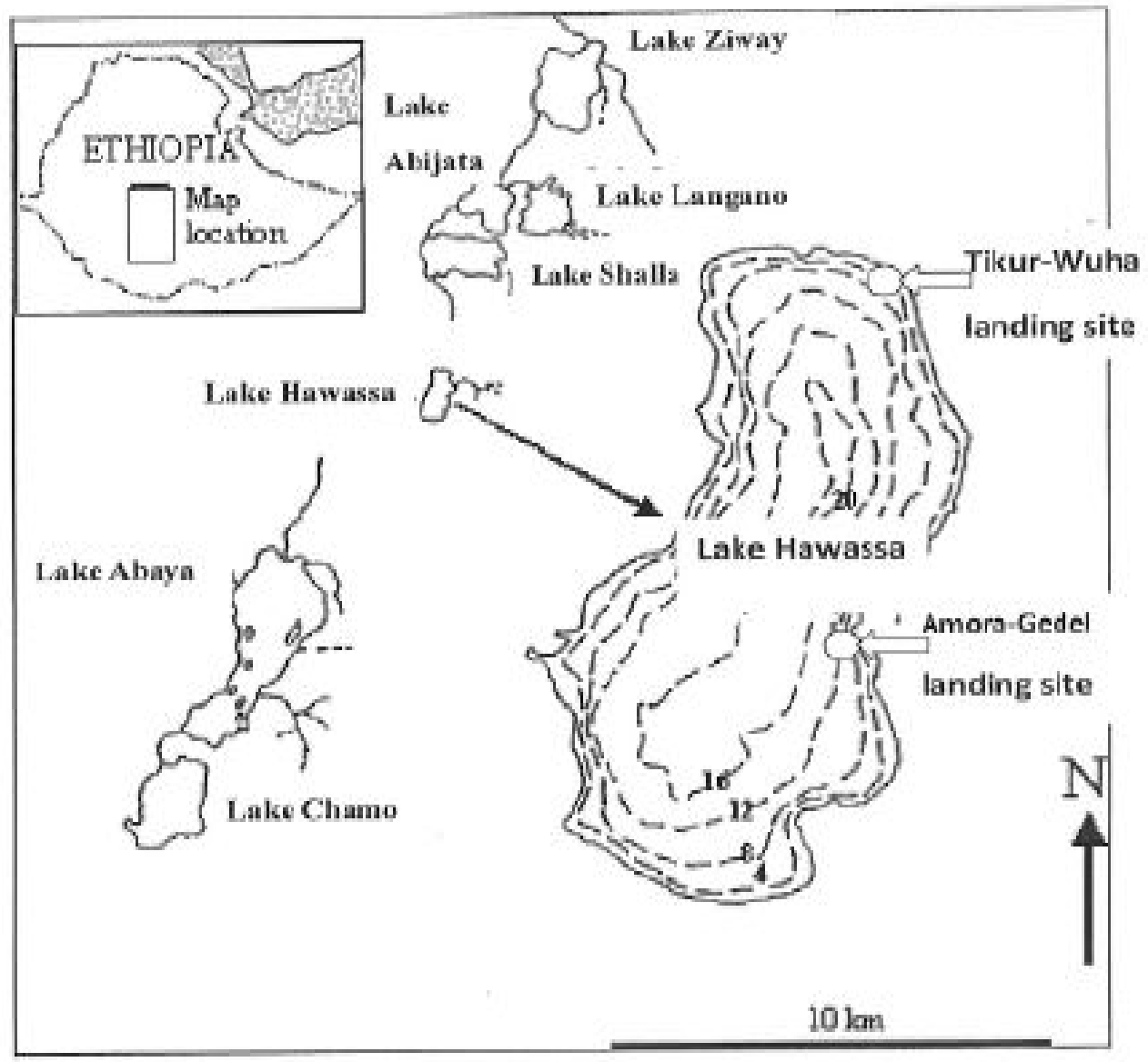

Figure 1: Map of Lake Hawassa shown together with the seven natural rift valley lakes. Contour lines are bathymetric lines at four meters interval. The fish landing sites of the northern and southern fisheries are also indicated. Inset: map of Ethiopia showing the lake region (modified from Zerihun Desta, 2007).

Two groups of fishermen cooperatives operate, one in the southern and the other in the northern part of the lake. The former land their catch at the southeastern shore at a place locally known as 'Amora-Gedel (Figure 1), which is also a fish market where the fishermen retail their catch. This cooperative has 270 fishermen and they have a long history of fishing experience. They have been fishing since commercial fishery was established some five decades ago (LFDP, 1997). The second groups of fishermen cooperative that operate at the northern part of the lake compose 37 fishermen and it is relatively recent, established less than a decade ago. They land their catch in the northern side of the lake at a place called 'Tikur-Wuha', which is the entry point of the Tikur-Wuha River (Figure 1). Due to conflicting interest between the two groups of fishermen, the fishing grounds of the northern and southern fishery do not overlap, which in turn has left some free zone in between. In other words, the fishermen that operates in the southern side fish at the southern one-third of the lake while those in the north fish at about one-third of the northern part of the lake area. Thus the middle part of the lake is a kind of buffer zone. 


\section{Sampling regime and data collection}

Data were collected on daily basis from both landing sites (Amora Gedel and Tikur-Wuha). Sampling was done from Amora-Gedel landing site between May 2012 and June 2013 for 296 days (Table 1). Data collection from Tikur-Wuha landing site was conducted for one year between June 2012 and May 2013 during which time 119 days were effectively sampled. The collected data constituted information on the fishery of $O$. niloticus that are useful to assess the stock and estimate biologically and economically sustainable yield as well as optimum level of fishing effort $\left(f_{\text {opt }}\right)$ to be expanded on the stock. Specifically the basic information collected on daily basis from each boat included i) the length composition of $O$. niloticus caught by each boat, ii) total $O$. niloticus yield per boat, iii) fishing effort expanded per boat, iv) number of fishermen in operation daily and, v) fishing site and retail price of fish of different sizes. During each sampling day, random samples of 30 to 50 fish were taken from each boat, and their length was measured to the nearest $\mathrm{mm}$. The total weight of the measured fish was recorded as a group to the nearest gram and the total catch of each boat was weighed. The latter data was then used to estimate the total number of $O$. niloticus caught by the respective boat. When many boats arrived at the same time, some of them would start selling fish before data on the total catch were recorded. In such situations, the total number of nets set and the fishing site were recorded in order to estimate the catch of missed boats using the catch per unit effort data of boats that fished at that particular site. In addition, data were collected regarding the retail price of fish during each sampling day. Fishermen used to sell their fish catches by sorting them into different sizes. Generally tilapia below $22 \mathrm{~cm}, 23-25 \mathrm{~cm}$ and above $26 \mathrm{~cm}$ were categorized as small, medium and large size fish, respectively. The retail price of these three size groups varied from time to time. Accordingly, the length of some (1015) fish was measured from each size group and the retail price of the respective length group was recorded. In addition, information on the cost of fishing was recorded occasionally. Regarding this, data collected included information that enabled estimation of the cost of boat making, cost of net making and labor cost of fishing operation separately for the two landing sites (Table 2).

\section{Data summarization and analysis}

The catch data were summarized in a manner useful for stock assessment using Jones length based cohort analysis model (Jones, 1984) and length-based Thompson and Bell yield prediction model (Thompson and Bell, 1934; Sparre and Venema, 1992). The catch data collected from the two landing sites were separately analyzed and interpreted. The summarization and analysis were done by using Microsoft Office Excel 2010 software. Accordingly, the length composition of catch data of $O$. niloticus were summarized to prepare a table of the length composition of the total annual catch of fish and this was done as follows (Pauly, 1984; Sparre and Venema, 1992):

\section{Preparing length frequency of the sample catch}

Length measurements recorded daily were grouped into one centimeter length intervals to prepare a table of the length frequency of O.niloticus sampled each day during the sampling occasions. The lengths and weights of a total of 179,815 fish were measured from Amora-Gedel landing site during the 296 days of sampling whereas those of 13,606 fish were measured from Tikur-Wuha 
landing site during the 119 days of sampling (Table 3). Overall, 193,457 fish were measured and the length frequency produced using such a large sample size was considered as adequate to give a good picture of the length frequency of the catch of O. niloticus in the lake.

\section{Estimating the total number of fish landed per day by each boat}

This was estimated by multiplying the number of length measured fish taken from each boat by a conversion factor $(\mathrm{W} / \mathrm{w})$ where $\mathrm{W}=$ the total weight of the catch of respective boat and $\mathrm{w}=$ sample weight of the length measured fish (Sparre and Venema, 1992). Thus, fish that were simultaneously counted and weighed were used to determine appropriate raising factor to convert records of the daily weight of the catch of respective boat into numbers.

\section{Estimating the length composition of the total daily catch}

This was achieved by multiplying the total numbers caught per day by the relative frequency of each length group in the daily sample obtained earlier. The total length frequency of fish landed during the sampled days was then determined by summing the frequencies of respective length groups (Sparre and Venema, 1992).

\section{Estimating the total number of $O$. niloticus} caught during the un-sampled days of the year

Fish price is expensive during the fasting days of the Ethiopian Orthodox Christianity (the dominant religion in the country) during which time consumption of all other animal products is not permitted, except fish. Accordingly, the catch and effort expanded by the fishery differed during the fasting and non-fasting days of the Ethiopian Orthodox Christians. Thus, the days of the year were divided into three categories as non fasting days of the week (i.e., days other than Wednesdays and Fridays), common fasting days of the week (Wednesday and Friday), and major fasting seasons, locally called 'Hudade', (i.e., 55 days often between February and April) as well as 'Filseta', (i.e., 15 days between August 7-22). Accordingly, the average catch, yield and effort data of the sampled non-fasting days was used to estimate the corresponding data of the unsampled non-fasting days. Similarly, the average data recorded during the sampled Wednesdays and Fridays was used to estimate the corresponding data of the un-sampled Wednesdays and Fridays. Likewise, the average daily data of the sampled major fasting days were used to estimate the corresponding data of the un-sampled major fasting days.

\section{Estimating the annual total length composition of landed fish}

This was done by multiplying the length frequency of the sampled days catch by an appropriate conversion factor which was equal to $\mathrm{C} / \mathrm{c}$, in which ' $\mathrm{C}$ ' = the estimated total catch of fish during the whole year and ' $c$ ' = the total catch of fish during the sampled days (Sparre and Venema, 1992).

\section{Estimating population size and fishing mortalities using Jones length based cohort analysis}

The Jones length based cohort analysis model (Jones, 1984) was used to estimate the fish 
population abundance and fishing mortality coefficient by length group of $O$. niloticus. This was done in three steps as follows:

\section{Estimating the population number of the largest} length group in the catch

The following equation was employed (Jones, 1984; Sparre and Venema, 1992)

$$
N_{\text {terminal }}=C_{\text {terminal }} *(\mathrm{Z} / F)_{\text {terminal }}------------(1)
$$

Where:

$\mathrm{N}_{\text {terminal }}=$ the population of the largest length group in the catch

$\mathrm{C}_{\text {terminal }}=$ the catch of the largest length group, and $(\mathrm{Z} / \mathrm{F})_{\text {terminal }}=$ the proportion of total mortality to fishing mortality of the largest length group in the catch.

\section{Estimating the population numbers of} consecutively younger length groups in the catch

This was done using the following equation:

$N\left(L_{1}\right)=\left\{N\left(L_{2}\right) * H\left(L_{1}, L_{2}\right)+C\left(L_{1}, L_{2}\right)\right\} * H\left(L_{1}, L_{2}\right)-\cdots----(2)$

Where:

$\mathrm{N}\left(\mathrm{L}_{1}\right)$ and $\mathrm{N}\left(\mathrm{L}_{2}\right)=$ the population of fish in the water that attained length $\mathrm{L}_{1}$ and $\mathrm{L}_{2}$, respectively

$\mathrm{C}\left(\mathrm{L}_{1}, \mathrm{~L}_{2}\right)=$ the total annual catch in number of fish caught between lengths $\mathrm{L}_{1}$ and $\mathrm{L}_{2}$ $\mathrm{H}\left(\mathrm{L}_{1}, \mathrm{~L}_{2}\right)=$ the fraction of $\mathrm{N}\left(\mathrm{L}_{1}\right)$ fish that survived natural deaths as it grows from length $\mathrm{L}_{1}$ to $\mathrm{L}_{2}$, and it is computed by the following equation (Jones, 1984)

$H\left(L_{1}, L_{2}\right)=\left[\frac{L \infty-L 1}{L \infty-L 2}\right]^{M / 2 k}$

Where:
$\mathrm{L}_{\infty}=$ the asymptotic length $(\mathrm{cm})$ of $O$. niloticus attained at mature size

$\mathrm{L}_{1}$ and $\mathrm{L}_{2}=$ consecutive length groups of fish $(\mathrm{cm})$ that contributed to the fishery

$\mathrm{K}=$ Von Bertalanffy growth rate constant $\left(\mathrm{yr}^{-1}\right)$

$\mathrm{M}=$ the rate of natural mortality coefficient for $O$. niloticus stock of Lake Hawassa.

Estimating the fishing mortality rate for the respective length groups

Fishing mortality values for each length group was estimated using the following equation.

$F(L 1, L 2)=\left\{\left(\frac{1}{\Delta t}\right) * \operatorname{Ln}\left[\frac{N(L 1)}{N(L 2)}\right]\right\}-M----------(4)$

Where

$\mathrm{F}\left(\mathrm{L}_{1}, \mathrm{~L}_{2}\right)=$ fishing mortality coeffecient pertaining to the respective length group $\mathrm{N}\left(\mathrm{L}_{1}\right), \mathrm{N}\left(\mathrm{L}_{2}\right)$ and $\mathrm{M}$ are as defined above. $\Delta t=$ the time required for fish of length $L_{1}$ to grow to length $\mathrm{L}_{2}$, and it is defined by the following equation (Jones, 1984; Pauly and Morgan, 1987; Gulland and Rosenberg, 1992).

$$
\Delta t=\left(\frac{1}{k}\right) * \operatorname{Ln}\left(\frac{L \infty-L 1}{L \infty-L 2}\right)
$$

The terms are as defined above.

To use equations $2,3,4$ and 5, the following input data and parameters were prepared in advance.

i) Firstly, a table of the total annual catch distributed by length group was prepared as described earlier.

ii) Secondly, estimates of the Von Bertalanffy growth parameters $\left(\mathrm{L}_{\infty}\right.$ and $\mathrm{K}$ ) for $O$. niloticus stock of Lake 
Hawassa were obtained from previous age determination work as $\mathrm{L}_{\infty}=35$ $\mathrm{cm}$ and $\mathrm{K}=0.28 \mathrm{yr}^{-1}$ (Yosef TekleGiorgis and Casselman, 1995; Demeke Admassu, 1998; Yosef Tekle-Giorgis, 2002).

iii) Thirdly, an estimate of the natural mortality coefficient (M) for O. niloticus stock of Lake Hawassa, which is equal to $0.35 \mathrm{yr}^{-1}$, was estimated using Pauly's empirical formula as follows (Pauly, 1984):

$\operatorname{Ln} M=0.00152-0.279 * \operatorname{Ln} L_{\infty}+0.6543 * \operatorname{Ln} K+0.463 * \operatorname{Ln} T------(6)$

Where values of $\mathrm{L}_{\infty}$ and $\mathrm{K}$ are as described above for $O$. niloticus stock and $\mathrm{T}$ is the mean annual surface water temperature of Lake Hawassa recorded during the study period, which was $21{ }^{\circ} \mathrm{C}$.

\section{Predicting bio-economically sustainable fish yield and optimum fishing effort}

The outputs of the above cohort analysis procedures were used as input data for the Thompson and Bell yield prediction model to predict sustainable fish yield at different levels of fishing mortalities (Thompson and Bell, 1934; Pauly and Morgan, 1987; Schnute, 1987; Sparre and Venema, 1992).

For the length based Thompson and Bell model, input data and sources comprised the following:

i. Length composition of the annual total number of fish landed by the fishery. This was obtained from field data collection (catch statistics data) as described earlier.

ii. Estimates of population numbers of fish and fishing mortality coefficient (F) by length group. Source: results of the Jones length based cohort analysis described earlier.

iii. An average estimate of natural mortality coefficient (M) and the Von Bertalanffy growth parameters $\left(\mathrm{L}_{\infty}\right.$ and $\left.\mathrm{K}\right)$. The same values discussed earlier have been used.

iv. Mean weight of the landings per length group. This was estimated by using the mean length of each length group and the lengthweight relationship formula expressed as follows:

I.

$W t(g)=a * L^{b}--------(7)$

Where: $\mathrm{Wt}(\mathrm{g})$ is the average weight of each length group, $\mathrm{L}=$ the average length $(\mathrm{cm})$ of each length group i.e., $\mathrm{L}=\left(\mathrm{L}_{1}+\mathrm{L}_{2}\right) / 2$ in which $\mathrm{L}_{1}$ and $\mathrm{L}_{2}$ are the length intervals of consecutive length groups. ' $a$ ' and ' $b$ ' are values of the regression coefficients.

To establish the above length-weight regression relationship, lengths and weights of a random sample of 2,000 O. niloticus that encompassed a wide range of length groups were measured. The total weight of fish landed per year in each length group was estimated by multiplying the average weights of each length group by the corresponding total annual catch of respective length group. The computation procedures of the Thompson and Bell yield model consisted of two main stages (Thompson and Bell, 1934) as described below.

\section{Estimating fish yield and gross revenue under the current level of effort}

The yield and gross revenue under the level of fishing effort expanded at the time of sampling was 
estimated using annual catch data, fish price and average weight of fish of respective length group. For this, first the yield in weight obtained per year from the respective length group of fish was calculated by multiplying the total annual catch in numbers of each length group by the mean weight of the respective length group. i.e.,

$Y(L 1, L 2)=C(L 1, L 2) * W(L 1, L 2)---------(8)$

Where:

$\mathrm{Y}\left(\mathrm{L}_{1}, \mathrm{~L}_{2}\right)=$ The yield (weight) of fish obtained per year from respective length group

$\mathrm{C}\left(\mathrm{L}_{1}, \mathrm{~L}_{2}\right)=$ Total annual catch of fish of respective length group

$\mathrm{W}\left(\mathrm{L}_{1}, \mathrm{~L}_{2}\right)=$ The mean weight of each length group estimated using equation 7

In a similar manner, gross revenue obtained from the sale of respective length group was obtained by multiplying the catch of respective length group by the average price of each length group.

$R(L 1, L 2)=C(L 1, L 2) * P(L 1, L 2)------(9)$

Where:

$\mathrm{R}\left(\mathrm{L}_{1}, \mathrm{~L}_{2}\right)=$ Gross revenue obtained per year from the sale of fish of respective length group

$\mathrm{C}\left(\mathrm{L}_{1}, \mathrm{~L}_{2}\right)=$ Total annual catch of fish of respective length group

$\mathrm{P}\left(\mathrm{L}_{1}, \mathrm{~L}_{2}\right)=$ Mean price of respective length group

Summing the yield and revenue obtained from each length group gave estimates of the annual total yield and revenue obtained under the level of fishing efforts expanded on the stock. These estimates pertained to the fishing mortalities that corresponded to the level of fishing effort exerted on $O$. niloticus stock at the time of sampling.

\section{Yield and profit predictions under different levels of fishing effort}

The second step in the calculation procedure involved assessment of the effects of changes in the current level of fishing effort (and hence that of fishing mortalities) on sustainable yield and economic value of the yield. This was done by predicting these outputs at higher and/or lower levels of fishing mortality coefficients pertaining to the respective length groups (F-at-lengtharray). The current fishing mortality values of the respective length groups estimated following the Jones length-based cohort analysis were used as reference, and these were increased and/or decreased by a certain raising factor (F-factor) to predict new values of sustainable yield and net profit obtained from sale of the catch corresponding to the changed fishing mortalities (Venema et al., 1988; Spare and Venema, 1992). Details of the procedure are as follows.

\section{Estimating population abundance under the changed level of fishing mortality}

Since a change in fishing mortality obviously results in a change in population number of fish in the water, new estimates of population numbers in each length group need to be predicted under the changed fishing mortality condition. Thus the population numbers under the changed fishing mortality were calculated from the following exponential decay relationship (Schnute, 1987; Sparre and Venema, 1992). 
$N(L 2)=N(L 1) * e^{-Z n e w(L 1, L 2) * \Delta t(L 1, L 2)}-----(10)$

Where, $N\left(L_{1}\right)$ is the population number of length $L_{1}$ fish and $\mathrm{N}\left(\mathrm{L}_{2}\right)$ is the population number of length $\mathrm{L}_{2}$ fish. Also $\Delta \mathrm{t}\left(\mathrm{L}_{1}, \mathrm{~L}_{2}\right)$ is the time it takes for an average fish to grow from length $\mathrm{L}_{1}$ to length $\mathrm{L}_{2}$ and it is defined earlier by equation 5 . $\operatorname{Znew}\left(\mathrm{L}_{1}\right.$, $\mathrm{L}_{2}$ ) is the total mortality under the changed level of fishing, which is equal to the sum of the changed fishing mortality and natural mortality coefficient i.e.,

Znew $(L 1, L 2)=$ Fnew $(L 1, L 2)+M$

Where:

Fnew $\left(\mathrm{L}_{1}, \mathrm{~L}_{2}\right)$ is the changed (new) fishing mortality coefficient of each length group. $\mathrm{M}$ is the natural mortality coefficient estimated by equation 6 above.

\section{Estimating the total death and catch in each length group under the changed fishing level}

The total number of deaths expected while the fish grew from length $\mathrm{L}_{1}$ to length $\mathrm{L}_{2}$, i.e., $\mathrm{D}\left(\mathrm{L}_{1}, \mathrm{~L}_{2}\right)$ under the changed fishing level, is equal to $N\left(L_{1}\right)$ $-\mathrm{N}\left(\mathrm{L}_{2}\right)$. From this total death, the fraction died due to fishing make up the total catch. Accordingly, the catch per length interval corresponding to the changed fishing mortality $\left[\mathrm{C}\left(\mathrm{L}_{1}, \mathrm{~L}_{2}\right)\right]$ was calculated from the following relationship (Wetherall et al., 1987).

$C(L 1, L 2)=[N(L 1)-N(L 2)] * \frac{F(\text { new })}{Z(\text { new })}----($

Where:

$\mathrm{F}$ (new) and $\mathrm{Z}$ (new) are the fishing and total mortality coefficients, respectively, under the changed level of fishing effort.
To predict the expected annual yield $\left[\mathrm{Y}\left(\mathrm{L}_{1}, \mathrm{~L}_{2}\right)\right]$ and gross revenue $\left[R\left(L_{1}, L_{2}\right)\right]$ obtained from respective length groups under the changed fishing mortality, the expected catch in number under the changed fishing level was multiplied by the mean weight and price of each length group, respectively, as illustrated by equations 8 and 9 . The total annual yield and gross revenue to be expected under the new level of fishing effort were then predicted by summing up the contributions of each length group. Then to predict the net profit obtained from the sale of fish under the changed fishing mortality, first the current total cost of fishing shown in table 2 was multiplied by respective F-factor to predict the cost of fishing under the changed F. Then the net profit under each level of fishing was predicted by deducting the predicted cost from the predicted gross revenue.

Such predictions were evaluated for different values of fishing mortalities so as to see the full spectrum of the effect of changing fishing effort on the stock. From this analysis, the value of F-factor that gave the maximum sustainable yield was considered as the biologically optimum level of fishing mortality $\left(\mathrm{f}_{\mathrm{MSY}}\right)$ to be exerted on the stock. Correspondingly, the level of F-factor at which the economic value of the yield would be maximum was considered as economically optimum level of fishing mortality $\left(\mathrm{f}_{\mathrm{MEY}}\right.$ ) that should be expanded to get the maximum return from the fishery (Sparre and Venema, 1992). Since there is a one-to-one correspondence between fishing mortality (F) and fishing effort (f), the value of F-factor chosen as optimum was used to recommend how much the current level of fishing effort need to be increased or decreased to get the maximum sustainable and bio-economical yield from the stock. 


\section{RESULTS}

\section{Status of $\boldsymbol{O}$. niloticus fishery of Lake Hawassa}

As noted above, the two cooperatives operating on the southern (Amora-Gedel landing site) and in the northern part (Tikur-Wuha landing site) of the lake have 270 and 37 fishermen, respectively (Table 1). . These fishermen set on average 337 and 272 nets daily at the southern and northern part of the fishing grounds using 43 and 14 boats, respectively. The boats are plank rowing boats, and five to seven fishermen share one boat to set their gillnets at Amora-Gedel landing site, while two to three fishermen operate per boat at Tikur-Wuha landing site.

The nets were basically set to catch $O$. niloticus, but these nets also caught some $C$. gariepinus and rarely $L$. intermedius. The nets used by the two cooperatives were similar. Each net was on average $80 \mathrm{~m}$ long and $2.5 \mathrm{~m}$ deep with stretched mesh size of $6-8 \mathrm{~cm}$ on average. Overall, an estimated number of 133,540 nets were operated during the sampling period at the southern part out of which the catch of 95,533 nets $(71.5 \%)$ were effectively sampled (Table 1). Also comparable proportion of nets $(70.5 \%$ of the total 99,360$)$ was effectively sampled at the northern part of the lake. Overall 123,086 and 99,360 nets were operated per year at the southern and northern parts of the fishing grounds, respectively. With these levels of fishing efforts, an estimated total number of 1,098,817 (240.2 tons) and 684,195 (215.4 tons) of $O$. niloticus was landed at Amora-Gedel and TikurWuha landing sites, respectively (Table 1). The catch per unit effort of the southern and northern fishery was $8.93 \mathrm{fish} / \mathrm{net}(1.95 \mathrm{~kg} / \mathrm{net})$ and 6.89 fish $/$ net $(2.18 \mathrm{~kg} / \mathrm{net})$, respectively.

The cost of fishing operation is similar per unit fishing gear at both fishing grounds but since more

Table 1. Statistics of O. niloticus fishery of Lake Hawassa operating at the southern (Amora-Gedel) and northern (Tikur-Wuha) parts of the lake.

\begin{tabular}{lll}
\hline \multirow{2}{*}{ Operation measure } & \multicolumn{2}{l}{ Landing site } \\
\cline { 2 - 3 } & Amora-Gedel & Tikur-Wuha \\
\hline Duration of sampling & May 2012-June 2013 & June 2012-May 2013 \\
Number of days effectively sampled & 296 days & 119 days \\
Number of fishermen in operation/day & 270 & 37 \\
Average number of boats in use /day & 43 & 14 \\
Total number of nets set during the sampled days & 133,540 & 99,360 \\
Total number of nets effectively sampled & 95,533 & 70,137 \\
Total nets set per year & 123,086 & 99,360 \\
Total annual yield (tons/year) & 240.23 & 216.33 \\
Total annual catch (number/year) & $1,098,817$ & 684,195 \\
Average number of nets set day & 337 & 272 \\
Catch/ day (number) & 3,011 & 1,875 \\
Fish yield /day (kg) & 658.2 & 592.7 \\
Catch per unit effort (number/net) & 8.93 & 6.89 \\
Yield per unit effort (kg/net) & 1.95 & 2.18 \\
\hline
\end{tabular}


number of fishing gears (boats and nets) were used at the southern part (Amora-Gedel), the total cost of fishing operation was considerably high (about 2.5 times higher) compared to the total cost incurred per year at the northern part of the lake (Table 2). Overall an estimated total cost of 960,340 Birr and 388,940 Birr per year was expended by the cooperatives at the southern and northern part of the Lake for fishing, respectively. These costs were used as inputs to make economic analysis of the fishing operation of the respective fishery (Table 2).

Table 2. Cost of fishing operation at Lake Hawassa shown for the two fisheries.

\begin{tabular}{|c|c|c|}
\hline Variable & Northern fishery & Southern fishery \\
\hline \multicolumn{3}{|l|}{ Cost of boat } \\
\hline Price of one boat (Birr) & 2,000 & 2,000 \\
\hline Service year of a boat (year) & 5 & 5 \\
\hline Cost of a boat per year (Birr) & 400 & 400 \\
\hline Number of boats used per year & 43 & 14 \\
\hline Total cost of boat per year (Birr) & 17,200 & 5,600 \\
\hline
\end{tabular}

\section{Cost of net making}

Cost of netting twine/roll (Birr)

$42 \quad 42$

Number of twine rolls needed for one net

$12 \quad 12$

Labor cost for making net/roll (Birr)

20

20

Rope cost/net (Birr)

$145 \quad 145$

Floater cost/net (Birr)

$50 \quad 50$

Service year of a net (years)

22

Total cost of one net (Birr)

Total cost of one net per year

Total nets used per year

337

Total cost of net per year (Birr)

\section{Labor cost (Birr)}

Cost of fishing person/day (Birr) $25-25$

Person required to operate per boat

22

Number of boat in use 43 2

Total labor cost/day for fishing (Birr) 2,150 700

Total labor cost per year for fishing (Birr) $\mathbf{7 8 4 , 7 5 0}$ 255,500

Table 3 shows the length frequency of $O$. niloticus in the sampled catch as well as in the estimated annual catch landed at Amora-Gedel and TikurWuha landing sites. As shown in columns 2 and 5 , the length and weight of a total of 179,851 and
13,606 fish were measured at Amora-Gedel and Tikur-Wuha landing sites, respectively. Thus, the length frequency of fairly large sample was used to estimate the length distribution of the total annual catch of $O$. niloticus shown in columns 3 and 6. 
O. niloticus measuring from $14 \mathrm{~cm}$ to $\geq 34 \mathrm{~cm}$ total length (TL) composed the catch of fishermen from both landing sites but fish below $18 \mathrm{~cm}$ were rare in the catch, particularly at Tikur-Wuha landing site. The proportion of larger sized fish was high at Tikur-Wuha than at Amora-Gedel landing site. At Amora-Gedel landing site, fish measuring between $19-26 \mathrm{~cm}$ composed greater than $90 \%$ of the catch and the modal catch was $22-23 \mathrm{~cm}$ TL (Table 3) whereas at Tikur-Wuha landing site about $80 \%$ of the catch ranged in size between 21 to $29 \mathrm{~cm}$ TL and the modal catch was 24-25 cm TL. Fish measuring $\geq 30 \mathrm{~cm}$ TL composed nearly $14 \%$ of the catch at Tikur-Wuha landing site while this size group composed less than $1 \%$ of the catch at Amora-Gedel landing site (Table 3).

Table 3. Length measured fish and estimated total annual catch by length group of tilapia landed at AmoraGedel (southern fishery) and Tikur-Wuha (northern fishery) landing sites.

\begin{tabular}{|c|c|c|c|c|c|c|}
\hline \multirow{2}{*}{$\begin{array}{l}\text { Length } \\
\text { group } \\
\text { (cm) }\end{array}$} & \multicolumn{3}{|c|}{ Southern Fishery (Amora-Gedel) } & \multicolumn{3}{|c|}{ Northern fishery (Tikur-Wuha) } \\
\hline & $\begin{array}{l}\text { Length } \\
\text { measured } \\
\text { fish }\end{array}$ & $\begin{array}{l}\text { Annual } \\
\text { catch } \\
\text { (number) }\end{array}$ & $\begin{array}{l}\% \text { contribution of } \\
\text { each length group }\end{array}$ & $\begin{array}{l}\text { Length } \\
\text { measured } \\
\text { fish }\end{array}$ & $\begin{array}{l}\text { Annual } \\
\text { catch } \\
\text { (number) }\end{array}$ & $\begin{array}{l}\% \text { contribution } \\
\text { of each length } \\
\text { group }\end{array}$ \\
\hline $14-15$ & 9 & 54 & 0.005 & 1 & 37 & 0.005 \\
\hline $15-16$ & 46 & 226 & 0.021 & 1 & 43 & 0.006 \\
\hline $16-17$ & 175 & 1,147 & 0.1 & 2 & 118 & 0.02 \\
\hline $17-18$ & 979 & 5,558 & 0.5 & 4 & 166 & 0.02 \\
\hline $18-19$ & 3,912 & 22,486 & 2.1 & 50 & 2,708 & 0.4 \\
\hline $19-20$ & 10,205 & 60,069 & 5.5 & 201 & 11,900 & 1.7 \\
\hline $20-21$ & 21,239 & 125,642 & 11.5 & 578 & 31,304 & 4.6 \\
\hline $21-22$ & 30,407 & 181,643 & 16.6 & 820 & 40,367 & 5.9 \\
\hline $22-23$ & 36,225 & 219,735 & 20.0 & 1,591 & 79,768 & 11.7 \\
\hline $23-24$ & 33,055 & 206,347 & 18.8 & 1,752 & 84,946 & 12.4 \\
\hline $24-25$ & 21,257 & 132,832 & 12.1 & 1,901 & 91,901 & 13.4 \\
\hline $25-26$ & 11,470 & 73,289 & 6.7 & 1,619 & 81,953 & 12 \\
\hline $26-27$ & 5,817 & 36,340 & 3.3 & 1,321 & 64,710 & 9.5 \\
\hline $27-28$ & 2,633 & 17,205 & 1.6 & 1,008 & 51,958 & 7.6 \\
\hline $28-29$ & 1,212 & 8,181 & 0.7 & 1,025 & 47,588 & 6.9 \\
\hline $29-30$ & 550 & 3,809 & 0.3 & 494 & 25,025 & 3.7 \\
\hline $30-31$ & 314 & 2,237 & 0.2 & 489 & 29,460 & 4.3 \\
\hline $31-32$ & 153 & 935 & 0.1 & 308 & 15,877 & 2.3 \\
\hline $32-33$ & 92 & 529 & 0.05 & 219 & 13,099 & 1.9 \\
\hline $33-34$ & 46 & 252 & 0.02 & 114 & 5,974 & 0.9 \\
\hline$\geq 34$ & 87 & 300 & 0.03 & 108 & 5,293 & 0.8 \\
\hline Total & 179,851 & $1,098,817$ & 100 & 13,606 & 684,195 & 100 \\
\hline
\end{tabular}

Estimates of population abundance, fishing mortality coefficient, current yield and revenue by length group of $O$. niloticus that composed the fishery
Tables 4 shows estimates of population number of fish and fishing mortality coefficient by length group of $O$. niloticus that composed the fishery of southern and northern part of the lake. Estimates 
of population number $\left[\mathrm{N}\left(\mathrm{L}_{1}\right)\right]$ and fishing mortality coeffecients $\left[\mathrm{F}\left(\mathrm{L}_{1}, \mathrm{~L}_{2}\right)\right]$ are direct outputs of the Jones' length based cohort analysis computed using equations 2 and 4, respectively. A population close to 16 million $O$. niloticus has been estimated to exist at the southern fishing ground of the lake as obtained by summing the population number of the respective length groups that composed the fishery shown by column 2 (Table 4). This estimate for the fishing ground at the northern part of the lake was over 15 million (Column 4), which is failry comparable to the estimate obtained for southern part of the lake. The area of the fishing grounds of the two fisheries is also fairly comparable as each cooperative operates at about one-third of the lake area at each side leaving the middle one-third of the area as buffer zone. Unlike the population at the southern part of the lake, proportionally larger sized fish composed the population at the northern part of the lake. The length group $\geq 27$ $\mathrm{cm}$ composed nearly $6 \%$ of the fish population at the northen part, but this size group composed only less than $1 \%$ of the total population at the southern part of the lake.

Table 4. Population number and fishing mortalities by length group estimated based on data collected from the southern (Amora-Gedel) and northern (Tikur-Wuha) fishery.

\begin{tabular}{|c|c|c|c|c|}
\hline \multirow[b]{2}{*}{$\begin{array}{l}\text { Length } \\
\text { group }(\mathrm{cm})\end{array}$} & \multicolumn{2}{|c|}{ Southern fishery } & \multicolumn{2}{|c|}{ Northern fishery } \\
\hline & $\begin{array}{l}\text { Population } \\
\text { number } \\
{[\mathrm{N}(\mathrm{L} 1)]}\end{array}$ & $\begin{array}{l}\text { Fishing Mortality } \\
\text { coefficient }\left(\mathrm{yr}^{-1}\right) \\
{[\mathrm{F}(\mathrm{L} 1, \mathrm{~L} 2)]}\end{array}$ & $\begin{array}{l}\text { Population } \\
\text { number } \\
{[\mathrm{N}(\mathrm{L} 1)]}\end{array}$ & $\begin{array}{l}\text { Fishing Mortality } \\
\text { coefficient }\left(\mathrm{yr}^{-1}\right) \\
{[\mathrm{F}(\mathrm{L} 1, \mathrm{~L} 2)]}\end{array}$ \\
\hline $14-15$ & $2,175,846$ & 0.0002 & $1,663,746$ & 0.0002 \\
\hline $15-16$ & $2,052,877$ & 0.0007 & $1,580,943$ & 0.0002 \\
\hline $16-17$ & $1,931,198$ & 0.0033 & $1,498,994$ & 0.0005 \\
\hline $17-18$ & $1,810,151$ & 0.0165 & $1,417,860$ & 0.0007 \\
\hline $18-19$ & $1,686,484$ & 0.0681 & $1,337,601$ & 0.012 \\
\hline $19-20$ & $1,548,502$ & 0.1898 & $1,255,836$ & 0.0537 \\
\hline $20-21$ & $1,377,685$ & 0.4324 & $1,166,320$ & 0.1458 \\
\hline $21-22$ & $1,150,346$ & 0.7299 & $1,059,847$ & 0.1972 \\
\hline $22-23$ & 881,598 & 1.1395 & 947,832 & 0.4221 \\
\hline $23-24$ & 594,372 & 1.5801 & 801,919 & 0.5064 \\
\hline $24-25$ & 342,319 & 1.6848 & 658,265 & 0.6384 \\
\hline $25-26$ & 181,892 & 1.6261 & 515,979 & 0.6861 \\
\hline $26-27$ & 92,829 & 1.4266 & 392,222 & 0.6649 \\
\hline $27-28$ & 47,573 & 1.1619 & 293,449 & 0.6643 \\
\hline $28-29$ & 25,186 & 0.9053 & 214,115 & 0.7875 \\
\hline $29-30$ & 13,841 & 0.6501 & 145,376 & 0.5382 \\
\hline $30-31$ & 7,981 & 0.5727 & 104,076 & 0.8584 \\
\hline $31-32$ & 4,377 & 0.3497 & 62,604 & 0.6718 \\
\hline $32-33$ & 2,506 & 0.2787 & 38,456 & 0.8442 \\
\hline $33-34$ & 1,314 & 0.1911 & 19,926 & 0.6213 \\
\hline$\geq 34$ & 600 & 0.35 & 10,587 & 0.35 \\
\hline Total & $15,929,477$ & & $15,185,952$ & \\
\hline
\end{tabular}


As estimated by the model, over two millions of O. niloticus measuring 14 to $15 \mathrm{~cm}$ were recruited to the fishery every year at the southern part of the lake (Table 4, column 2, first row). This estimate, based on data collected from the catch landed at the northern part of the lake, was over 1.6 million fish (Table 4 column 4, first row). Accordingly, these estimates were fairly comparable.
Table 5 gives estimates of total annual yield (tons) and revenue (Birr) obtained from the sale of $O$. niloticus under the level of fishing effort exerted at the time of sampling. The mean weight of fish $(\mathrm{kg})$ shown in column 2 is the average weight of each length group of $O$. niloticus estimated using the length-weight relationship expressed by the following equation:

Table 5. Estimates of total yield and annual revenue obtained from the sale of $O$. niloticus of the respective length group under the current level of fishing effort expanded at the time of sampling by the southern and northern fishery.

\begin{tabular}{|c|c|c|c|c|c|c|c|c|}
\hline \multirow[b]{2}{*}{$\begin{array}{l}\text { Length } \\
\text { group } \\
(\mathrm{cm})\end{array}$} & \multirow[b]{2}{*}{$\begin{array}{l}\text { Mean } \\
\text { weight } \\
(\mathrm{kg})\end{array}$} & \multirow[b]{2}{*}{$\begin{array}{l}\text { Fish } \\
\text { price } \\
\text { (Birr) }\end{array}$} & \multicolumn{3}{|c|}{ Southern fishery } & \multicolumn{3}{|c|}{ Northern fishery } \\
\hline & & & $\begin{array}{l}\text { Current } \\
\text { annual } \\
\text { catch } \\
\text { (number) }\end{array}$ & $\begin{array}{l}\text { Current } \\
\text { annual } \\
\text { yield(tons) }\end{array}$ & $\begin{array}{l}\text { Gross } \\
\text { revenue } \\
\text { (Birr) }\end{array}$ & $\begin{array}{l}\text { Current } \\
\text { annual } \\
\text { catch } \\
\text { (number) }\end{array}$ & $\begin{array}{l}\text { Current } \\
\text { annual } \\
\text { yield(tons) }\end{array}$ & $\begin{array}{l}\text { Gross } \\
\text { revenue } \\
\text { (Birr) }\end{array}$ \\
\hline $14-15$ & 0.053 & 2 & 54 & 0.003 & 108 & 37 & 0.002 & 74 \\
\hline $15-16$ & 0.065 & 2 & 226 & 0.015 & 452 & 43 & 0.003 & 86 \\
\hline $16-17$ & 0.079 & 3 & 1,147 & 0.09 & 3,441 & 118 & 0.009 & 354 \\
\hline $17-18$ & 0.094 & 3 & 5,558 & 0.524 & 16,674 & 166 & 0.016 & 498 \\
\hline $18-19$ & 0.112 & 4 & 22,486 & 2.518 & 89,944 & 2,708 & 0.303 & 10,832 \\
\hline $19-20$ & 0.132 & 4 & 60,069 & 7.912 & 240,276 & 11,900 & 1.567 & 47,600 \\
\hline $20-21$ & 0.154 & 4 & 125,642 & 19.31 & 502,568 & 31,304 & 4.811 & 125,216 \\
\hline $21-22$ & 0.178 & 4 & 181,643 & 32.335 & 726,572 & 40,367 & 7.186 & 161,468 \\
\hline $22-23$ & 0.205 & 4 & 219,735 & 45.005 & 878,940 & 79,768 & 16.338 & 319,072 \\
\hline $23-24$ & 0.234 & 6 & 206,347 & 48.331 & $1,238,082$ & 84,946 & 19.896 & 509,676 \\
\hline $24-25$ & 0.266 & 6 & 132,832 & 35.38 & 796,992 & 91,901 & 24.478 & 551,406 \\
\hline $25-26$ & 0.301 & 6 & 73,289 & 22.085 & 439,734 & 81,953 & 24.696 & 491,718 \\
\hline $26-27$ & 0.339 & 6 & 36,340 & 12.33 & 218,040 & 64,710 & 21.956 & 388,260 \\
\hline $27-28$ & 0.38 & 8 & 17,205 & 6.544 & 137,640 & 51,958 & 19.764 & 415,664 \\
\hline $28-29$ & 0.425 & 8 & 8,181 & 3.475 & 65,448 & 47,588 & 20.21 & 380,704 \\
\hline $29-30$ & 0.472 & 8 & 3,809 & 1.799 & 30,472 & 25,025 & 11.821 & 200,200 \\
\hline $30-31$ & 0.524 & 8 & 2,237 & 1.171 & 17,896 & 29,460 & 15.423 & 235,680 \\
\hline $31-32$ & 0.578 & 8 & 935 & 0.541 & 7,480 & 15,877 & 9.182 & 127,016 \\
\hline $32-33$ & 0.637 & 10 & 529 & 0.337 & 5,290 & 13,099 & 8.342 & 130,990 \\
\hline $33-34$ & 0.699 & 10 & 252 & 0.176 & 2,520 & 5,974 & 4.178 & 59,740 \\
\hline$\geq 34$ & 1.162 & 14 & 300 & 0.349 & 4,200 & 5,293 & 6.153 & 74,102 \\
\hline Total & & & $1,098,817$ & 240.23 & $5,422,769$ & 684,195 & 216.33 & $4,230,356$ \\
\hline
\end{tabular}


$\mathrm{W}=0.0184^{*} \mathrm{~L}^{3.0197}, \quad \mathrm{R}^{2}=0.96$

Where, $\mathrm{W}$ is the average weight in grams of each length group and L is the average length of respective length groups in centimeters. The coefficient of determination $\left(\mathrm{R}^{2}\right)$ value for the relationship was 0.96 indicating that the estimated total weight for the respective length group is 96 $\%$, which is related to the measured weight of each length group. Also the mean price of fish shown by column 3 is the average retail price of respective length group of fish.

Values in columns 4 and 7 (Table 5) are annual catch of respective length group of fish landed at Amora-Gedel (southern fishery) and Tikur-Wuha (northern fishery) landing sites, respectively, which displayed here to illustrate the intermediary calculation steps. The current total yield per year pertaining to the respective length group (columns 5 and 8) were obtained by multiplying the total catch per year of the respective length group by the corresponding mean weight values as depicted by equation 8 . The estimated annual total yield of $O$. niloticus landed by the southern and northern fishery was $240.23 \mathrm{t} /$ year and $216.33 \mathrm{t}$ /year, respectively. There was a yield difference of $24 \mathrm{t} /$ year between the two fisheries, and this could be because of fishing pressure difference exerted by the two fisheries.

Gross revenues obtained from the sale of $O$. niloticus landed at the two lading sites are shown for respective length group in columns 6 and 9 (Table 5). They were obtained by multiplying the catch of each length group by the corresponding retail price of the respective length group as shown by equation 9. Accordingly, an estimated total annual gross revenue of over 5.4 million Birr was obtained from the sale of $O$. niloticus landed by the southern fishery, and the corresponding estimate for the northern fishery was over 4.2 million Birr/year.
Predicted yield, revenue, cost and net profit obtained from $O$.niloticus fishery under different levels of fishing efforts

Summary of predicted annual yield, revenue, cost of fishing and net profit obtained from $O$. niloticus of the two fisheries are shown using values of F-factors ranging from 0.1 to 2 (Tables 6 and 7, Figure 2). Predictions were made based on the length based Thompson and Bell model following the procedures depicted under subsection 2.5.2. The reference F-array is shown in columns 3 and 5 of Table 4. It has been multiplied by each value of F-factor shown in column 1 of Tables 6 and 7 to produce the new fishing mortality coefficient for each length group. Then values of yield and revenue (columns 2 and 3, Tables 6 and 7) were predicted using the new F-array. Column 4 (Tables 6 and 7) shows total annual cost of fishing of the two fishery obtained by multiplying the current total cost of fishing obtained at the time of sampling (Table 2) by the F-factor shown in column 1 of Tables 6 and 7. Column 5 (Tables 6 and 7) shows the predicted net profit obtained per year from the two fisheries obtained by deducting the predicted annual cost (values of column 4, Tables 6 and 7) from the predicted annual gross revenue (values of column 3, Tables 6 and 7).

Based on data collected from Amora-Gedel landing site, a maximum predicted yield (MSY) of 240.2 $\mathrm{t} / \mathrm{year}$ is obtained from the fishery at the southern part of the lake at an F-factor of 1 (Table 6). On the other hand, a predicted maximum net annual profit of Birr 4,531,792 can be generated from the fishery at an F-factor of 0.8 . This implies that a maximum return from the southern fishery can be obtained if the fishing pressure at the time of sampling (F-current) is reduced by $20 \%$. Regarding the fishery at the northern part of the lake, the analysis 
showed that the predicted yield becomes maximum (MSY) at an F-factor of 1.5, but the profit becomes maximum (Birr 3,907,981) at an F-factor of 1.4 (Table 7). This indicates that the fishery at the northern part of the lake can have small room for expansion, and the level of fishing effort that was exerted at the time of data collection (i.e., 272 nets/ day) can be increase by about $40 \%$.

Table 6. Predicted annual yield (t/year), gross revenue, cost and net profit (Birr) obtained from O.niloticus fishery at the southern part of Lake Hawassa.

\begin{tabular}{|c|c|c|c|c|c|}
\hline \multirow[b]{2}{*}{ F-factor } & \multicolumn{5}{|c|}{ Southern fishery } \\
\hline & Yield (tons) & $\begin{array}{l}\text { Annual gross } \\
\text { (Birr) }\end{array}$ & revenue & $\begin{array}{l}\text { Total annual cost } \\
\text { (Birr) }\end{array}$ & $\begin{array}{l}\text { Net annual profit } \\
\text { (Birr) }\end{array}$ \\
\hline 0.1 & 100.2 & $1,942,464$ & & 96,034 & $1,846,430$ \\
\hline 0.2 & 158.6 & $3,170,793$ & & 192,068 & $2,978,725$ \\
\hline 0.3 & 193.1 & $3,959,959$ & & 288,102 & $3,671,857$ \\
\hline 0.4 & 213.6 & $4,474,412$ & & 384,136 & $4,090,276$ \\
\hline 0.5 & 225.7 & $4,814,302$ & & 480,170 & $4,334,132$ \\
\hline 0.6 & 232.8 & $5,041,611$ & & 576,204 & $4,465,407$ \\
\hline 0.7 & 236.8 & $5,195,267$ & & 672,238 & $4,523,029$ \\
\hline $0.8\left(\mathrm{f}_{\mathrm{opt}}\right)$ & 238.9 & $5,300,064$ & & 768,272 & $4,531,792$ \\
\hline 0.9 & 239.9 & $5,372,006$ & & 864,306 & $4,507,700$ \\
\hline 1 (Current f) & 240.2 & $5,422,769$ & & 960,340 & $4,462,429$ \\
\hline 1.1 & 240.1 & $5,455,699$ & & $1,056,374$ & $4,399,325$ \\
\hline 1.2 & 239.6 & $5,479,067$ & & $1,152,408$ & $4,326,659$ \\
\hline 1.3 & 239.1 & $5,494,860$ & & $1,248,442$ & $4,246,418$ \\
\hline 1.4 & 238.4 & $5,505,282$ & & $1,344,476$ & $4,160,806$ \\
\hline 1.5 & 237.7 & $5,511,880$ & & $1,440,510$ & $4,071,370$ \\
\hline 1.6 & 236.9 & $5,515,754$ & & $1,536,544$ & $3,979,210$ \\
\hline 1.7 & 236.2 & $5,517,699$ & & $1,632,578$ & $3,885,121$ \\
\hline 1.8 & 235.4 & $5,518,294$ & & $1,728,612$ & $3,789,682$ \\
\hline 1.9 & 234.7 & $5,517,967$ & & $1,824,646$ & $3,693,321$ \\
\hline 2 & 234.0 & $5,517,039$ & & $1,920,680$ & $3,596,359$ \\
\hline
\end{tabular}

NB bold and shaded values correspond to predictions at $\mathrm{f}_{\text {opt }}$ 
Table 7. Predicted annual yield (t/year), gross revenue, cost and net profit (Birr) obtained from O.niloticus fishery at the northern part of Lake Hawassa.

\begin{tabular}{|c|c|c|c|c|c|}
\hline \multirow[b]{2}{*}{ F-factor } & \multicolumn{5}{|c|}{ Northern fishery } \\
\hline & Yield (tons) & $\begin{array}{l}\text { Annual gross } \\
\text { (Birr) }\end{array}$ & revenue & Total annual cost (Birr) & $\begin{array}{l}\text { Net annual profit } \\
\text { (Birr) }\end{array}$ \\
\hline 0.1 & 71.4 & $1,157,400$ & & 38,894 & $1,118,506$ \\
\hline 0.2 & 118.9 & $1,985,585$ & & 77,788 & $1,907,797$ \\
\hline 0.3 & 150.8 & $2,589,245$ & & 116,682 & $2,472,563$ \\
\hline 0.4 & 172.6 & $3,036,731$ & & 155,576 & $2,881,155$ \\
\hline 0.5 & 187.5 & $3,373,646$ & & 194,470 & $3,179,176$ \\
\hline 0.6 & 197.8 & $3,630,991$ & & 233,364 & $3,397,627$ \\
\hline 0.7 & 204.9 & $3,830,202$ & & 272,258 & $3,557,944$ \\
\hline 0.8 & 209.8 & $3,986,325$ & & 311,152 & $3,675,173$ \\
\hline 0.9 & 213.1 & $4,110,075$ & & 350,046 & $3,760,029$ \\
\hline 1(current) & 215.4 & $4,230,356$ & & 388,940 & $3,841,416$ \\
\hline 1.1 & 216.9 & $4,289,292$ & & 427,834 & $3,861,458$ \\
\hline 1.2 & 217.9 & $4,354,590$ & & 466,728 & $3,887,862$ \\
\hline 1.3 & 218.4 & $4,408,202$ & & 505,622 & $3,902,580$ \\
\hline $1.4\left(\mathrm{f}_{\mathrm{opt}}\right)$ & 218.6 & $4,452,497$ & & 544,516 & $3,907,981$ \\
\hline 1.5 & 218.7 & $4,489,291$ & & 583,410 & $3,905,881$ \\
\hline 1.6 & 218.5 & $4,519,986$ & & 622,304 & $3,897,682$ \\
\hline 1.7 & 218.3 & $4,545,681$ & & 661,198 & $3,884,483$ \\
\hline 1.8 & 218.0 & $4,567,244$ & & 700,092 & $3,867,152$ \\
\hline 1.9 & 217.6 & $4,585,367$ & & 738,986 & $3,846,381$ \\
\hline 2 & 217.1 & $4,600,605$ & & 777,880 & $3,822,725$ \\
\hline
\end{tabular}

NB bold and shaded values correspond to predictions at $f_{\text {opt }}$ 


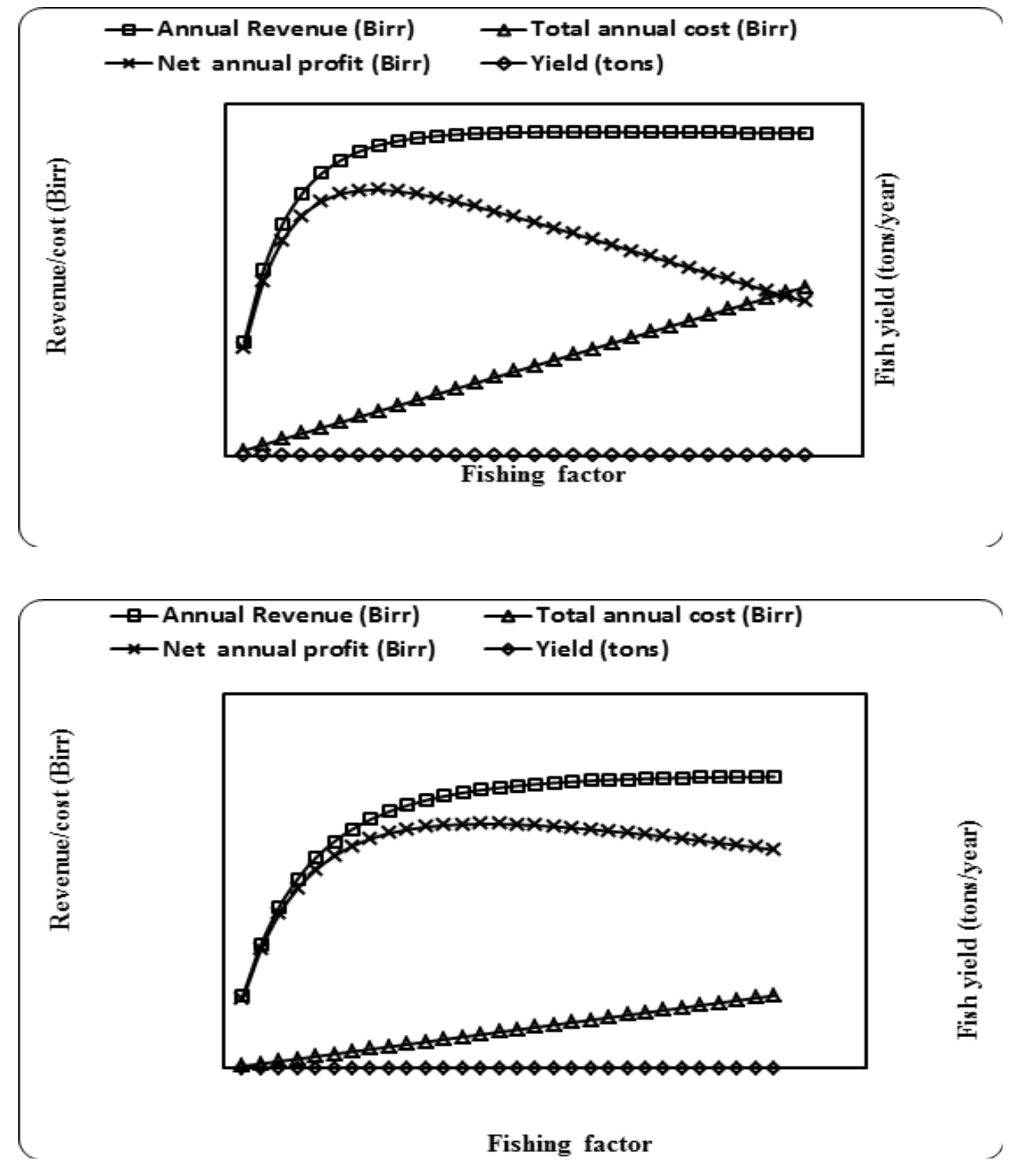

Figure 2: Predicted annual yield (t/year), revenue, cost and net profit (Birr) obtained from O. niloticus fishery of Lake Hawassa at different levels of fishing factor shown for southern (a) and northern (b) fishery.

\section{DISCUSSION}

\section{Status of $O$. niloticus fishery of Lake Hawassa}

Commercial fishery started in the 1950's in Lake Hawassa (LFDP, 1997). Until fishery at the northern part of the lake started eight years ago Amora-Gedel landing site, which is located at the south eastern shore of the lake, was the only landing site where fishermen retailed their catch. Fishermen of Lake Hawassa use manual rowing boats to set their nets and bring their catch to the landing sites. Since fishermen have to bring their catch to the retail site early in the morning, the southern part of the lake, which is located close to the fish landing site, is the most intensively fished part of the lake. On the other hand, since intensified fishery and fish landing at the northern part of the lake started in recent years, this part of the lake is relatively less fished compared to its southern part.

The difference in length composition of the catch of the southern and northern fishery is an indication of the intensity of fishing in the two 
fishing grounds. Proportionately larger fish are more abundant in the catch of the northern fishery compared to the catch of the southern fishery where fish larger than $30 \mathrm{~cm}$ are very rare in the catch. The catch per unit effort (8.93 fish/net) at the southern fishery is more than the average catch per net (6.89 fish/net) of the northern fishery. But yield per unit effort of the northern fishery (2.18 $\mathrm{kg} / \mathrm{net}$ ) is higher than the corresponding value (1.95 $\mathrm{kg} / \mathrm{net}$ ) at the southern fishery. This is because of the fact that the catch of the southern fishery is composed of smaller sized fish. Obviously, this is a response to intensive fishing (Bwanika, et al. 2004) conducted at the southern fishing grounds.

More than $90 \%$ of the catch of the southern fishery is composed of the size group 19-26 cm and the modal catch size is $22-23 \mathrm{~cm}$ TL. Compared to the size distribution of the catch reported some 15 to 20 years ago, there appears to be quite a shift towards exploiting younger $O$. niloticus by the southern fishery. For instance, according to LFDP (1997), O. niloticus measuring between 20 and $30 \mathrm{~cm}$ TL composed about $97 \%$ of the catch and the modal catch was 24-25 TL. Similarly in the samples of fish taken from fishermen's catch in 2002, the length group 20 to $28 \mathrm{~cm} \mathrm{TL}$ accounted for $95 \%$ of the catch with modal catch of $24 \mathrm{~cm}$ (Yosef Tekle-Giorgis, 2002). The size distribution of fish landed some two decades ago was fairly similar to the catch distribution landed at the northern part of the lake in the present day. - However, some three to four decades ago, when the fishery was relatively at its early stage, $O$. niloticus measuring up to 35 to $40 \mathrm{~cm}$ TL were very common in fishermen's catch with modal catch size of 25 to $30 \mathrm{~cm}$ TL (LFDP, 1997). This was the time when the fishing pressure was fairly low and the fishermen were using mesh sizes $\geq 10$ cm stretched width.
According to Yosef Tekle-Giorgis (2002), the length at first maturity of $O$. niloticus in Lake Hawassa was about $20 \mathrm{~cm}$ TL. In the present result, fish $\leq 20 \mathrm{~cm}$ TL composed about $10 \%$ the catch of the southern fishery (Table 3). On the other hand, only few proportions of fish $(\approx 2 \%)$ were caught below $20 \mathrm{~cm}$ TL by the northern fishery . This indicates that some portion of the fishermen's catch in the southern part is composed of immature O.niloticus that might not have yet reproduced at least once in their lifespan Thus, it seems reasonable to slightly increase the mesh width of nets used by the fishermen of the lake in general.

More than $70 \%$ of the catch of C. gariepinus, the other fish species caught mainly by gillnets in Lake Hawassa, is composed of sizes less than $40 \mathrm{~cm}$ TL, which are largely immature as the length at first maturity of this fish is $45 \mathrm{~cm}$ TL (Tesfaye Mulye, et al., 2016). Thus the mesh of nets used at Lake Hawassa should be widened in order to protect the capture of immature C. gariepinus population. To be precise, nets below $8 \mathrm{~cm}$ mesh width should be totally prohibited from being used by fishermen of Lake Hawassa.

\section{Estimates of population abundance, yield, revenue and optimum level of fishing for $O$. niloticus stock}

A population of about 16 million of $O$. niloticus has been estimated to exist at the southern part of the lake and this estimate was similar with the population abundance estimated for the northern part of the lake (over 15 million fish). Since the fishing grounds of the two fisheries were comparable, it is expected that the two areas harbor same abundance of fish. Overall, a population of about 30 million $O$. niloticus exists in Lake Hawassa, and this estimate is fairly comparable 
to the estimate reported by Ryntjens and Tesfaye Wudneh (1998) as 28 million fish. On the other hand, the current estimate is slightly higher than the estimate given by Yosef Tekle-Giorgis (2002) as 20 million fish.

Some 2 millions of $O$. niloticus recruit to the fishery annually attaining a size of $14-15 \mathrm{~cm}$ at the southern part of the lake, which is fairly comparable to the annual recruitment at the northern part (over 1.5 million fish). Overall, a total of about 4 million $O$. niloticus recruit to the fishery annually in Lake Hawassa and this estimate is fairly comparable to the estimates reported by other workers for $O$. niloticus population of Lake Hawassa. For instance, Yosef TekleGiorgis (2002) estimated that an average number of about 5 millions of $O$. niloticus had recruited annually to the fishery attaining a length of 15 to $16 \mathrm{~cm}$. Reyintjens and Tesfaye Wudneh (1998) also reported that an average number of about 5.6 million $O$. niloticus recruited to the fishery of Lake Hawassa attaining a total length of $16 \mathrm{~cm}$. Given that recruitment considerably varies from year to year, the present finding was fairly comparable to the previous estimates.

In the present study, a total annual yield of 240.2 t/year and $215.4 \mathrm{t} /$ year of $O$. niloticus has been estimated for the southern and northern fishery, respectively, as obtained at the level of fishing pressure exerted at the time of sampling. This gives a total annual yield of $455.6 \mathrm{t} /$ year at the lake level, and this value is fairly lower compared to the annual yield estimates reported earlier for $O$. niloticus fishery of Lake Hawassa. For example, Reyintjens and Tesfaye Wudineh (1998) estimated a total annual yield of 520 tons of $O$. niloticus/year as harvested by the fishermen cooperatives of Lake Hawassa. The estimate in 2002 was about 540 t/ year (Yosef Tekle-Giorgis, 2002). The reduction in yield could be an indicative of the attainment of a new equilibrium of surplus production by the stock in response to fishing pressure that removed mega spawners.

Overall, an estimated gross revenue of over 5.4 million and 4.2 million Birr per year has been generated by the fishery at the southern and northern part of the lake, respectively. The revenue obtained from the northern fishery is only 1.2 million Birr less than the amount obtained from the southern fishery, but the catch landed at AmoraGedel was nearly double that of the catch landed at Tikur-Wuha. The reason for the relatively small revenue difference obtained from the two fisheries could be the larger size of fish landed at TikurWuha compared to the size of fish landed at AmoraGedel.

Analysis on data collected from the southern fishery indicated that a maximum sustainable yield of $240.2 \mathrm{t}$ /year can be obtained at an F-factor of 1 , which is the level of fishing pressure exerted at the time of sampling. However, the economically most profitable level of fishing that generates the maximum net revenue is at an F-factor of 0.8 implying that the fishing effort should be reduced by $20 \%$ to get the maximum return from the fishery. Thus, the level of fishing effort expanded at the time of sampling (i.e. 337 nets/day) should be reduced by $20 \%$ and the optimum level of fishing effort $\left(\mathrm{f}_{\text {opt }}\right)$ for the southern fishery should be 270 nets/day (98,550 net days/year). Regarding the northern fishery, a maximum return is obtained at an F-factor of 1.4, which suggests that the fishery can be increased by $40 \%$. Therefore, the level of fishing at the time of sampling (272 nets/day) can be increased to 380 nets per day to generate the maximum return from the fishery. 
In general, the present analysis showed that the optimum level of fishing effort $\left(f_{\text {opt }}\right)$ to be exerted at the lake level is about 650 nets/day in order to exploit the O. niloticus stock of Lake Hawassa sustainably. This effort is similar to the recommended safe level of fishing given by Reyintjens and Tesfaye Wudneh (1998) as 700 nets per day.

\section{ACKNOWLEDGEMENTS}

The author is grateful to the fishermen of Lake Hawassa for their cooperation during data collection and to Hawassa University Research and Development Directorate Office for financing this project.

\section{REFERENCES}

Bwanika, G.N., Makanga, B., Kizito, Y., Chapman, L.J and Balirwa, J. (2004). Observations on the biology of Nile tilapia, Oreochromis niloticus L., in two Ugandan crater lakes. African Journal of Ecology 42 (Suppl.1): 93-101.

Demeke Admassu. (1998). Age and growth determination of tilapia, Oreochromis niloticus L. (Pisces : Cichlidae) in some lakes in Ethiopia. Ph. D. Thesis, Addis Ababa University, Ethiopia.

Elias Dadebo. (2000). Reproductive biology and feeding habits of the catfish, Clarias gariepinus (Burchell) (Pisces: Clariidae) in Lake Awassa, Ethiopia. SINET: Ethiopian Journal of Science 23(2): 231-246.
Elizabeth Kebede. (1996). Phytoplankton in a salinity-alkalinity series of lakes in the Ethiopian rift valley. Ph. D. Thesis, Uppsala University, Uppsala, Sweden.

Gulland, J.A and Rosenberg, A.A. (1992). A review of length-based methods to assessing fish stocks. FAO Fisheries Technical Paper, 323, Rome.

Jones, R. (1984). Assessing the effects of changes in exploitation patterns using length composition data (with notes on VPA and Cohort analysis). FAO Fisheries Technical Paper, 256, Rome.

LFDP (1997). Lake management plans. Lake Fisheries Development Project, Phase II, Working Paper 23. $2^{\text {nd }}$ ed. Ministry of Agriculture, Addis Ababa.

Pauly, D. (1984). Fish population dynamics in tropical waters: a manual for use with programmable calculators. ICLARM, Philippines.

Pauly, D and Morgan, G.R. (1987). Length based methods in fisheries research .ICLARM Conference Proceedings 13,. 468 p, Manila, Philippines.

Reyntjens, D and Tesfaye Wudneh. (1998). Fisheries management - a review of the current status and research needs in Ethiopia. SINET: Ethiopian Journal of Science 21(2): 231-266.

Schnute, J. (1987). A general fishery model for a sizestructured fish population. Canadian Journal of Fisheries and Aquatic Science 44(5): 924-940.

Seyoum Mengistou and Fernando, C.H. (1991). Seasonality and abundance of some dominant crustacean zooplankton in Lake Awassa, 
a tropical rift valley lake in Ethiopia. Hydrobiologia 226: 137-152.

Sparre, P and Venema, S.C. (1992). Introduction

to tropical fish stock assessment. Part 1.

Manual. FAO Fisheries Technical Paper No. 306, Rome

Tadesse Fetahi and Seyoum Mengistou. (2007) Trophic analysis of Lake Awassa (Ethiopia) using mass-balance ecopath model. Ecological Modeling 201: 398-408

Tesfaye Muluye, Yosef Tekle-Giorgis and Girma Tilahun. (2016). The extent of immature fish harvesting by the commercial fishery of Lake Hawassa. Momona Ethiopian Journal of Science 8(1): 37-49.

Thompson, W.F and Bell, F.H. (1934). Biological statistics of the pacific halibut fishery.2. Effects of changes in intensity upon total yield and yield per unit of gear. Report of the international Fisheries (Pacific halibut) Commission, $8, .49 \mathrm{p}$.

Tudorancea, C., Baxter, R.M and Fernando, C.H. (1989). A comparative limnological study of zoobenthic associations in lakes of the Ethiopian rift valley. Archive für Hydrobiologie (Suppl.) 83: 121-174.

Venema, S.C.; Christensen, J.M and Pauly, D. (1988). Training in tropical fish stock assessment: a narrative of experience. FAO Fisheries Technical Paper 389, Rome

Wetherall, J.A., Polovina, J.J and Ralston, S. (1987). Estimating growth and mortality in steadystate fish stock from length-frequency data. ICLARM Conference Proceedings 13, 53-74 p, Philippines:
Yosef Tekle-Giorgis and Casselman, J.M. (1995). Increasing the precision of otolith age determination for tropical fish by differentiating biannual recruitment, p. 247-269. (Dean and S.E. Campan, eds.). Recent developments in fish otolith research. University of South Carolina press, Columbia.

Yosef Tekle-Giorgis. (2002). Comparative age and growth assessment of the African catfish, Clarias gariepinus Burchell (Clariidae) and, Nile perch, Lates niloticus, Linn (Centropomidae) in the three southern Rift Valley lakes of Ethiopia (Lakes Awassa, Abaya and Chamo). Ph. D. Thesis, Addis Ababa University, Ethiopia

Zerihun Desta. 2007. Food web structure and mercury transfer patterns in fish community of L. Hawassa, Ethiopia. Ph.D. Thesis. Norwegian University of Life Science, Ås, 59 pp. 